\title{
From Keynes to Friedman: Monetary Policy of 20th
}

\author{
Gürhan Uysal \\ Ondokuz Mayis University, Samsun, Turkey
}

\begin{abstract}
Research question includes affect of monetary policy on product's demand. Monetary policy may increase demands in markets for firm's products. Assumption of study is that markets need money for demand. It is figured as market theory. Research topic explores theory of market and world money concept. It aims to use world money in market theory. This study adopts case exploration of Keynes, Friedman, and Fisher. This study is based on their figures. This study defends that world money is applied in global economy by quantity of global GDP. It is 60 trillion dollars, and $10 \%$ of that amount may become world money. Result of this study is that world money concept is applied through Fisher's quantity theory in world economy. Major conclusion is that markets need money to increase demand, aligned with market theory, and world money supplies money for markets.
\end{abstract}

Keywords: market theory, monetary policy, J. M. Keynes, Milton Friedman, money, market demand

\section{Introduction}

There are two persons of modern economy in 20th century, Keynes and Friedman. This paper explores their monetary policy perspectives. Firstly, there are three quantity theories in modern economy. First one is presented by David Hume, before Adam Smith (Savas, 2007). Accepted theory of quantity is Fisher's quantity theory in 1900s (Skousen, 2011). It is based on M.V = P.T formula. This formula explores that, if money (M) is over of quantity in markets, that leads to increase in prices $(\mathrm{P})$.

Secondly, this study defends backfinance methodology as a monetary policy to hinder financial crises. Global financial system is based on financial derivatives. It may create financial crises such as 2008 process. Therefore, backfinance may stop financial crises.

\section{Literature Review}

\section{Keynesian Economy and Monetary}

Keynesian monetary aims to supply markets with money through public investment. This policy is called as IS-LM. IS-LM is presented by economists, John Hicks in 1937 after presentation of General Theory of Keynes, 1936 (Backhouse \& Bateman, 2006). Keynes impressed colleagues and economy in his era. Cambridge University was top economy school in that era with efforts of Alfred Marshall, Keynes, Hicks, Pigou, Hayek, Samuelson, Robinson, and others. London School of Economics appeared on academy after 1950s. Major policy of Keynes is budget deficit policy. This policy is implemented in global economy in 1950s; however, it resulted in hyperinflation in 1970s. Thus, Keynesian economy attracted critics from politics and academy.

Gürhan Uysal, associate professor/Ph.D., School of Business, Ondokuz Mayis University, Samsun, Turkey.

Corresponding concerning this article should be addressed to Gürhan Uysal, School of Business, Ondokuz Mayis University, Kurupelit Campus, 55139 Atakum-Samsun, Turkey. 
Further, Milton Friedman criticised Keynesian monetary system in 1970s (Aktan, 2008). He assumed that overmoney supply results in inflation in economy. Central bank must become independent to stop government's force of overmoney supply. Because Friedman said that budget deficit policy generates overmoney supply in economy.

\section{Monetarism and Supply Side Economy}

USA Government adopted monetarism policy and supply side policy to get out from stagflation of 1970s. Milton Friedman presented monetarism, and Prof. Arthur Laffer presented supply side economy (Aktan, 2008).

Keynesian Economy demanded side economy. J. M. Keynes aimed to increase total demand in economies by monetary policy of IS-LM. His assumption is that total demand would decrease unemployment level in economy.

\section{Research Methods}

This study is based on theories of J. M. Keynes and I. Fisher. Therefore, the study adopts their theories as a research methodology (i.e., IS-LM and quantity theory). For example, world money notion is based on I. Fisher's quantity theory. It adopts global GDP as an equation.

\section{Research Results}

\section{Market Theory and World Money}

Markets need money to increase demand, according to market theory. That policy is requirement of capitalism. Factory system is established for businesses in Industrial Revolution, and capitalism started with Industrial Revolution. Main result of factory system is scale of economy and mass production. Machine used in factories enabled companies of mass production and scale of economies. However, mass production needs consumptions and demands for markets.

If there is not demand, there would not become production behind, and it will generate unemployment. Market theory says that money results in demand in market, according to Figure 1 below. Because money is purchasing power of customers. So, market theory claims that market needs money for demand. Model is:

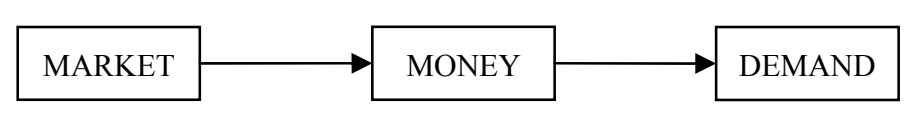

Figure 1. Market theory.

Thus, IMF may adopt "world money" concept to increase total demand in world economy. World Money concept is presented by J. M. Keynes in establishment of IMF in 1940s. Its name is "bancor". However, world money is applied by IMF as SDR notion currently. It is abbreviation of special drawing rights. Aim of SDR is to finance balanced payment deficits of national economies. So, world money may supply markets with money for increasing total demand. Because, due to less demand, less consumption, mass production, and isomorphism effect, business markets witness deflation rise. So, global economy may need "world money" policy.

Second advantage of world money, it may finance balanced payment deficit of national economies. It is similar to SDR policy.

However, equality of world money might become "global GDP" quantity. Global GDP are 60 trillion dollars in global economy. About $5 \%$ or $10 \%$ of this amount might become variable of world money. Thus, 
IMF may print five trillion dollars to finance balanced payment deficit each year. That print of money each year may increase total demand of global economy, and may finance cash needs of countries. That policy might not create inflation in global economy. That policy of world money may be sustained in global economy for the next 50 years in global. It has equation of quantity, according to quantity theory of Fisher, 1903, Yale University, for example, US government has 1.5 trillion \$ budget deficit. World money may finance this deficit. Golden standard collapsed in world economy due to 1929 process. For example, England left golden standard in 1931. After 1944, IMF, there is dollar standard in global economy.

\section{Analysis or Discussion}

This study presents world money concept. It is based on Irving Fisher's quantity theory. Central banks worldwide may print US dollars aligned with global GDP. World money would support cash needs of economies, for example, world money finance balanced payment deficits of countries.

Furthermore, world economy may have two perspectives, currently: full competitive structure and isomorphism. Those two dilemmas may result in demand problem in markets. Therefore, firms may struggle for demand problems in markets. Isomorphism is that products of firms resemble each other in market. Therefore, consumers have troubles for product choices. This paper suggests world money notion to increase demand in markets against firm's products.

\section{BackFinance and Financial Derivatives ${ }^{1}$}

This paper explores 2008 process with financial derivatives. Financial innovations appeared on economy during 1990s. They are, for example, swap, future, forward, option, etc., those are called as financial derivatives. Financial derivatives resulted in financial baloon during 2000s. There may be two reasons for 2008 Crises. They are financial baloon and mortgage baloon. Financial baloons, mortgage baloon, and debt problem of governments withdrew money from business markets, and that policy may result in recession in markets during 2008 process. Because 2008 is recession problem. Reason might become those baloons.

What if derivatives create baloon and recessions again? Back Finance methodology may be used to stop upcoming crise. Fed financed USA banks in 2008 process with 700 billion dollars. According to back finance, FED may have financed Europe banks. It is backfinance. So, USA Fed may finance Japanese banks to hinder new crises. In this chain, Japan would make its payment to European investors, and Europeans make its payment to USA investors. Thus, new financial crises and possible recession may stop. In conclusion, backfinance methodology may be used for global economy to prevent economies from new financial crises.

\section{Conclusions}

Crises of modern economy, or capitalism, appears in economy due to a lack of money in markets. If money disappears from economy, crises of economy start such a recession problem. Therefore, global economy and IMF should improve economic solutions for money problem of global economy. It may be world money notion against monetary problem of global economy. Solution of IMF might become world money notion with quantity as global GDP amount.

${ }^{1}$ Abstract for 11th Silkroad International Conference, Georgia. 


\section{References}

Aktan, C. C. (2008). Schools of economy. Ankara: Seckin Publishing House.

Backhouse, R. E., \& Bateman, B. W. (2006). Keynesian approach. Ankara: Dost Publishing.

Savas, V. F. (2007). History of economy. Ankara: Siyasal Publishing.

Skousen, M. (2011). History of economic thought. (A. Mustafar, Trans.). Ankara: Adres Publishing. 